\title{
LUMPUR PRIMER IPAL INDUSTRI KERTAS SEBAGAI BAHAN BAKU ALTERNATIF BIOETANOL
}

\author{
Saepulloh, Rina S. Soetopo, Prima Besty Asthary \\ Balai Besar Pulp dan Kertas \\ Jalan Raya Dayeuh Kolot No. 132 Bandung Telp. 022-5202980, 5202871 Fax. 022-5202871
}

Diterima : 06 Pebruari 2012, Revisi akhir : 25 Mei 2012

\author{
PAPER MILL WWTP PRIMARY SLUDGE \\ AS AN ALTERNATIVE RAW MATERIAL OF BIOETHANOL
}

\begin{abstract}
Primary sludge from paper mill waste water treatment plant (WWTP) is a potential raw material for ethanol production because of its high organic content especially cellulose. This study consisted of two main stage: cellulose hydrolisis and glucose fermentation. Primary sludge was hydrolyzed using cellulase with concentration of 10,20 , and $25 \mathrm{FPU} / \mathrm{g}$ cellulose under conditions of $\mathrm{pH} 5.5$ and temperature $50^{\circ} \mathrm{C}$ for 24, 48, 72, and 98 hours. Glucose obtained from hydrolis was fermented in optimum condition ( $p H$ 4.5 and temperature $28^{\circ} \mathrm{C}$ ) using $10 \%$ of Saccharomyces cerevisiae inoculum for 24, 48, 72, and 98 hours. The results showed that the optimum hydrolysis was achieved using cellulase 25 FPU within 72 hours with glucose content obtained was $1.92 \%$ and saccharification degree was $61.05 \%$. Ethanol produced from glucose fermentation was about $0.77 \%$ and fermentation degree was $78.5 \%$. Overall conversion yield was $46.61 \%$ and ethanol yield was $192.5 \mathrm{~g} / \mathrm{kg}$ dry weight.
\end{abstract}

Keywords: papermill primary sludge, cellulose, cellulase, Saccharomyces cerevisiae, bioethanol

\begin{abstract}
ABSTRAK
Lumpur primer dari IPAL industri kertas mempunyai potensi sebagai bahan baku untuk produksi bioetanol, karena kandungan organiknya yang tinggi terutama selulosa. Lumpur primer IPAL diperoleh dari industri kertas berbahan baku virgin pulp. Secara garis besar percobaan dilakukan dengan sistem dua tahap yaitu proses hidrolisis selulosa dan dilanjut proses fermentasi glukosa. Percobaan proses hidrolisis selulosa dilakukan pada $\mathrm{pH} 5,5$ dan suhu $50^{\circ} \mathrm{C}$ dengan 2 faktor perlakuan yaitu dosis selulase $(10,20$, dan $25 \mathrm{FPU} / \mathrm{g}$ selulosa) dan lama proses hidrolisis (24, 48, 72, dan 96 jam), sedangkan percobaan proses fermentasi dilakukan terhadap glukosa hasil proses hidrolis pada kondisi optimumnya. Proses fermentasi dilakukan pada $\mathrm{pH} 4,5$ dan suhu $28^{\circ} \mathrm{C}$ menggunakan ragi Saccharomyces cerevisiae sebanyak $10 \%$ dengan perlakuan lama inkubasi $(24 ; 48 ; 72 ; 96$ jam). Hasil percobaan menunjukkan bahwa kondisi optimum proses hidrolisis diperoleh pada dosis selulase $25 \mathrm{FPU} / \mathrm{g}$ selulosa selama $72 \mathrm{jam}$, dengan kadar glukosa $1,92 \%$ dan derajat sakarifikasi $61,05 \%$. Kadar etanol yang diperoleh dari proses fermentasi glukosa hasil hidrolisis adalah $0,77 \%$ dengan efisiensi fermentasi $78,5 \%$. Secara keseluruhan efisiensi konversi selulosa pada lumpur primer IPAL industri kertas menjadi etanol adalah 46,61\% dengan yield sebesar $192 \mathrm{~g} / \mathrm{kg}$ berat kering.
\end{abstract}

Kata kunci: lumpur primer industri kertas, selulosa, selulase, Saccharomyces cerevisiae, bioetanol 


\section{PENDAHULUAN}

Industri kertas menghasilkan limbah padat dalam jumlah cukup besar sekitar 3-4\% dari total produksi (Soetopo dkk., 2010), yang sebagian besar berupa lumpur (sludge) dari Instalasi Pengolahan Air Limbah (IPAL). Dengan diberlakukannya UU RI No. 32 tahun 2009 tentang Perlindungan dan Pengelolaan Lingkungan Hidup (PPLH) yang makin ketat, mendorong industri kertas untuk selalu meningkatkan efektivitas pengelolaan limbahnya. Pengelolaan lumpur IPAL industri kertas umumnya dilakukan dengan cara dibuang ke landfill atau dibakar, namun cara tersebut bukan pilihan yang tepat, karena dapat berpotensi mencemari tanah, air tanah, dan udara (Peng dan Chen, 2011). Untuk menghindari atau mengurangi terjadinya pencemaran lingkungan, saat ini pengelolaan lumpur IPAL di industri kertas lebih banyak dilakukan dengan cara memanfaatkan potensinya.

Secara umum terdapat dua jenis lumpur IPAL dari industri kertas yaitu lumpur primer yang berasal dari sistem pengolahan air limbah secara fisika-kimia dan lumpur sekunder yang berasal dari sistem pengolahan air limbah secara biologi. Lumpur primer mengandung banyak senyawa organik dalam bentuk serat selulosa. Jumlah serat selulosa dalam lumpur primer tersebut sangat bervariasi tergantung pada jenis kertas yang diproduksi, bahan baku yang digunakan, teknologi yang diterapkan, dan kualitas kertas yang ingin dihasilkan (Monte dkk., 2009). Limbah serat selulosa dalam lumpur primer IPAL industri kertas, memiliki potensi untuk dimanfaatkan sebagai bahan baku bioetanol. Pemanfaatan tersebut, selain menghasilkan produk etanol sebagai bahan bakar alternatif yang ramah lingkungan, juga dapat mengatasi permasalahan penyediaan lahan (landfill) untuk pembuangan lumpur (Gavrilescu, 2008).

Bioetanol termasuk ke dalam biofuel yang merupakan sumber energi alternatif dan berpotensi sebagai pengganti bahan bakar fosil. Bessou dkk. (2011) menjelaskan bahwa kelebihan bioetanol dari bahan bakar fosil adalah dapat terbarukan dan menghasilkan lebih sedikit emisi gas rumah kaca $\left(\mathrm{CO}_{2}\right)$. Silva dkk. (2011) menjelaskan bahwa lumpur primer IPAL industri kertas dapat dihidrolisis secara enzimatik tanpa proses pretreatment terlebih dahulu dengan derajat sakarifikasi yang diperoleh sebesar $69,5 \%$ yang relatif lebih tinggi dibandingkan dengan derajat sakarifikasi hidrolisis enzimatik unbleached pulp yaitu sebesar 27,2\%. Selain itu, Peng dan Chen (2011) menjelaskan bahwa konversi lumpur IPAL industri kertas menjadi etanol dengan cara Separate Hydrolysis and Fermentation (SHF) menggunakan Saccharomyces cerevisiae menghasilkan perolehan (yield) sebesar $190 \mathrm{~g}$ etanol per kg berat kering lumpur.

Fan dan Lynd (2007), Lynd dkk.( 2001) dan Kerstetter dkk.(1996) menjelaskan beberapa kelebihan pemanfaatan lumpur IPAL industri kertas sebagai bahan baku bioetanol dibandingkan dengan biomasa selulosa lainnya, yang antara lain adalah sebagai berikut:

- pengadaan bahan baku lumpur primer IPAL yang merupakan limbah industri kertas relatif tidak terbebani biaya,

- lumpur primer IPAL industri kertas telah melalui proses delignifikasi sehingga kandungan selulosanya tinggi, dan

- menghemat biaya investasi dan produksi karena terintegrasi dengan pengelolaan lingkungan dari pabrik kertas.

Artikel ini menjelaskan hasil penelitian tentang potensi lumpur IPAL industri kertas sebagai bahan baku bioetanol. Proses yang digunakan adalah sistem dua tahap yang diawali dengan proses hidrolisis selulosa pada lumpur primer IPAL yang kemudian dilanjutkan dengan proses fermentasi glukosa hasil hidrolisis menjadi etanol. Proses hidrolisis dilakukan secara enzimatik dengan selulase dan proses fermentasi dilakukan secara mikrobiologi dengan Saccharomyces cereviceae.

\section{BAHAN DAN METODE}

Bahan yang digunakan dalam penelitian ini adalah lumpur primer IPAL dari industri kertas yang menggunakan bahan baku virgin pulp. Lumpur tersebut diambil dari primary clarifier. Enzim yang digunakan dalam percobaan proses hidrolisis adalah selulase komersial dari Novozyme (Celluclast 1.5L). Ragi untuk proses fermentasi glukosa adalah Saccharomyces cerevisiae yang diperoleh dari Laboratorium Mikrobiologi ITB. Beberapa bahan kimia yang digunakan antara lain: natrium dihidrogen fosfat $\left(\mathrm{NaH}_{2} \mathrm{PO}_{4}\right)$; dinatrium hidrogen fosfat $\left(\mathrm{Na}_{2} \mathrm{HPO}_{4}\right)$; asam sulfat $\left(\mathrm{H}_{2} \mathrm{SO}_{4}\right) 5 \%$; natrium 
hidroksida (NaOH); medium Potatoes Dextrose Agar (PDA) dan medium Potatoes Dextrose Broth (PDB). Beberapa peralatan yang digunakan antara lain mesin penggiling (milling), waterbath shaker, sterilizer, laminar air flow, dan botol fermentor.

Secara garis besar penelitian dilakukan dalam beberapa tahap kegiatan yaitu karakterisasi dan perlakuan awal lumpur IPAL; percobaan penentuan kondisi optimum proses hidrolisis; dan percobaan proses fermentasi glukosa. Uraian masing-masing tahap adalah sebagai berikut:

\section{Karakterisasi dan Perlakuan Awal Lumpur Primer IPAL}

Karakterisasi lumpur primer IPAL meliputi beberapa parameter yaitu selulosa, hemiselulosa, alfa selulosa, dan lignin yang pengujiannya dilakukan dengan metoda standar menurut SNI. Perlakuan awal terhadap lumpur primer IPAL sebelum digunakan sebagai bahan percobaan adalah pengeringan dan penggilingan. Pengeringan dilakukan dengan cara dikeringanginkan, sedangkan penggilingan dilakukan untuk memperoleh lumpur yang homogen pada ukuran sekitar 60 mesh.

\section{Percobaan Penentuan Kondisi Optimum Proses Hidrolisis}

Percobaan proses hidrolisis dilakukan dalam Erlenmeyer $250 \mathrm{~mL}$. Lumpur primer IPAL dengan kadar padatan total 4\% dan $\mathrm{pH} 5,5$ dilarutkan dengan aquades sehingga volumenya $100 \mathrm{~mL}$. Proses hidrolisis dilakukan pada water bath shaker dengan kecepatan $110 \mathrm{rpm}$, dan suhu $50^{\circ} \mathrm{C}$. Variasi percobaan terdiri dari dua faktor yaitu dosis selulase $(10,20$, dan 25 FPU/g selulosa) dan waktu hidrolisis (24, 48, 72, dan 96 jam) serta masing-masing perlakuan dilakukan replikasi dua kali. Efektivitas proses hidrolisis diketahui dengan melakukan analisis glukosa sebagai gula pereduksi dengan metode Smogyi-Nelson (Nelson, 1952). Perhitungan efektivitas proses hidrolisis dilakukan dengan cara menghitung derajat sakarifikasi seperti disajikan dalam persamaan sebagai berikut:

$$
\text { Derajat Sakarifikasi }=\frac{\text { Kadar Glukosa Uji }}{\text { Kadar Glukosa Teoritis }} \times 100 \%
$$

\section{Percobaan Proses Fermentasi Glukosa menjadi Bioetanol}

Percobaan proses fermentasi merupakan lanjutan dari proses hidrolisis. Lumpur primer IPAL yang telah mengalami proses hidrolisis pada kondisi optimumnya, hasilnya kemudian difermentasi. Proses fermentasi dilakukan pada $\mathrm{pH} 4,5$ dan suhu $28^{\circ} \mathrm{C}$ menggunakan ragi Saccharomyces cerevisiae sebanyak 10\% dengan perlakuan lama inkubasi $(24 ; 48 ; 72 ; 96$ jam). Pengukuran kadar etanol dilakukan setiap 24 jam dengan menggunakan kromatografi gas yang dilakukan di Universitas Padjajaran Bandung.

\section{HASIL DAN PEMBAHASAN}

\section{Karakteristik Lumpur Primer IPAL Industri Kertas}

Hasil analisis karakteristik lumpur primer IPAL industri kertas berbahan baku virgin pulp dapat dilihat pada Tabel 1. Berdasarkan data pada Tabel 1 tersebut, menunjukkan bahwa kandungan selulosa pada lumpur IPAL cukup tinggi dengan nilai di atas $70 \%$. Nilai tersebut lebih tinggi dibandingkan dengan kandungan selulosa dari limbah pertanian seperti tongkol jagung yang mengandung selulosa sebanyak 35$40 \%$, jerami gandum $33-50 \%$, dan jerami padi $36-47 \%$ (Wang dan Keshwani, 2010). Tingginya kandungan selulosa dalam lumpur primer IPAL industri kertas, menunjukkan bahwa lumpur tersebut memiliki potensi untuk dijadikan bahan baku bioetanol. Kandungan lignin pada lumpur primer IPAL industri kertas relatif rendah bila dibandingkan dengan kandungan lignin pada hardwood dan softwood yaitu masing-masing berkisar 20\%-25\% dan 27\%-30\% serta limbah pertanian seperti jerami yang mengandung lignin pada kisaran 10\%-24\% (Wang dan Keshwani, 2010).

Tabel 1. Karakteristik Lumpur Primer IPAL Industri Kertas

\begin{tabular}{ccc}
\hline No. & Parameter & Kadar $(\%)$ \\
\hline 1. & Selulosa & $73,46 \%$ \\
2. & Alfa selulosa & $32,43 \%$ \\
3. & Hemiselulosa & $4,24 \%$ \\
4. & Lignin & $1,38 \%$ \\
\hline
\end{tabular}


Rendahnya kandungan lignin pada lumpur primer IPAL industri kertas disebabkan oleh karena lumpur tersebut berasal dari industri kertas berbahan baku virgin pulp yang sudah diputihkan (bleached). Lignin umumnya terdapat dalam lumpur IPAL industri pulp yang sumbernya dari proses delignifikasi. Rendahnya kandungan lignin dalam lumpur IPAL industri kertas merupakan suatu keuntungan dalam proses pembuatan etanol dari selulosa. Lignin yang merupakan senyawa komplek fenol dan bisa terdegradasi menjadi turunan fenol dapat berpotensi sebagai penghambat proses hidrolisis selulosa secara enzimatik. Silva dkk. (2011) menjelaskan bahwa kandungan glukosa hasil konversi selulosa pulp yang tidak diputihkan akan lebih rendah dibandingkan konversi selulosa pulp yang diputihkan. Hal ini akibat dari tingginya kandungan lignin yang menghambat kerja enzim. Adanya komponen seperti tannin, gallik, hidroksil sinamik, dan asam 4-hidroksibenzoat, bersama dengan vanillin dapat menyebabkan deaktivasi selulase/ $\beta$-glukosidase sebesar $20-80 \%$ setelah inkubasi 24 jam (Ximenes dkk., 2011). Selain dari pada itu, rendahnya kandungan hemiselulosa pada lumpur IPAL juga merupakan suatu keuntungan, sesuai penjelasan Mussatto dkk (2008) bahwa semakin rendah kandungan hemiselulosa dan lignin, akan semakin besar tingkat efisiensi hidrolisis selulosa secara enzimatik.

Pada dasarnya, serat selulosa pada lumpur primer IPAL industri kertas sudah mengalami perlakuan proses mekanik/kimia sebelum menjadi limbah (Peng dan Chen, 2011; Kerstetter dkk., 1996). Hal itu ditunjukkan dengan kandungan lignin yang relatif rendah pada lumpur primer IPAL (Tabel 1) bila dibandingkan dengan kandungan lignin pada kayu yang menjadi bahan baku pulp. Meskipun demikian, pada percobaan ini tetap dilakukan perlakuan awal terhadap lumpur primer IPAL untuk menghaluskan ukuran partikel melalui penggilingan. Hal itu dilakukan karena penggilingan merupakan perlakuan awal mekanis yang dapat menurunkan tingkat kristalinitas selulosa dan meningkatkan aksesibilitas enzim (Cheng, 2010; Lee dkk, 2009).

\section{Kondisi Optimum Proses Hidrolisis}

Hasil percobaan penentuan kondisi optimum proses hidrolisis dapat dilihat pada Gambar 1 , yang menunjukkan bahwa seiring dengan makin tinggi dosis selulase dan makin lama waktu inkubasi, akan menghasilkan kadar gula pereduksi makin tinggi pula. Hal itu sejalan dengan hasil penelitian yang telah dilakukan oleh Peng dan Chen (2011), yang menjelaskan bahwa peningkatan kadar gula hasil hidrolisis selulosa terjadi seiring peningkatan dosis selulase dan waktu hidrolisis sampai kondisi optimum, selanjutnya peningkatan dosis selulase dan waktu hidrolisis tidak akan memberikan peningkatan kadar gula yang berarti. Berdasarkan variasi dosis selulase yang telah dilakukan pada percobaan ini, menunjukkan bahwa kadar glukosa sebagai gula pereduksi tertinggi diproduksi pada waktu inkubasi $72 \mathrm{jam}$.

Variasi dosis selulase $10 \mathrm{FPU} / \mathrm{g}, 20 \mathrm{FPU} / \mathrm{g}$, dan $25 \mathrm{FPU} / \mathrm{g}$ setelah 72 jam proses hidrolisis masingmasing secara berturut turut menghasilkan kadar glukosa $1,25 \% ; 1,68 \%$; dan $1,97 \%$ yang berbeda cukup signifikan. Pada percobaan ini, belum dapat ditentukan dosis selulase yang optimum, karena hasil percobaan masih menunjukkan kecenderungan kadar gula pereduksi yang makin tinggi sejalan dengan meningkatnya dosis selulase sampai $25 \mathrm{FPU} / \mathrm{g}$.

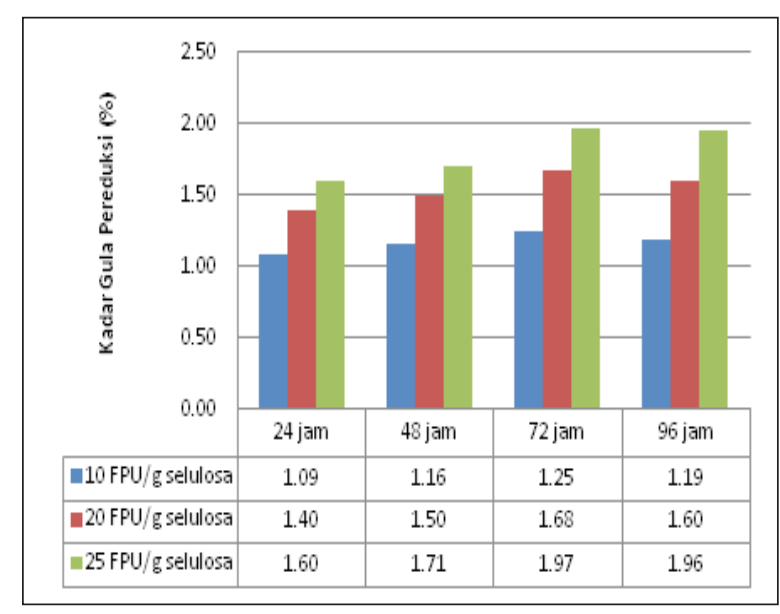

Gambar 1. Kadar Gula Pereduksi Hasil Hidrolisis Selulosa

Berdasarkan data derajat sakarifikasi pada Gambar 2, dapat dijelaskan bahwa peningkatan dosis selulase dan waktu hidrolisis selalu diikuti dengan peningkatan derajat sakarifikasi. Kenaikan derajat sakarifikasi diperoleh pada dosis selulosa tertinggi (25 FPU/g) yaitu $61,05 \%$ dengan waktu hidrolisis 72 jam. Nilai derajat sakarifikasi tersebut masih lebih rendah dibandingkan dengan hasil penelitian yang telah dilakukan oleh Silva dkk. (2011) yang menggunakan lumpur primer IPAL industri kertas 
berbahan baku kertas bekas dengan menggunakan gabungan enzim selulase (Celluclast 1.5L) dan cellobiase/ $\beta$-glukosidase (Novozyme 188) dapat mencapai derajat sakarifikasi sebesar $69,5 \%$. Salah satu faktor yang dapat menyebabkan rendahnya nilai derajat sakarifikasi pada penelitian ini adalah tidak digunakannya enzim $\beta$-glukosidase untuk menghidrolisis lebih lanjut selubiosa yang terbentuk. Selubiosa yang merupakan salah satu produk utama hidrolisis enzimatik selulosa menyebabkan gangguan proses difusi active site selulase pada molekul selulosa sehingga proses hidrolisis selulosa menjadi terhambat (Yue dkk., 2004). Lynd dkk. (2001) menjelaskan bahwa penambahan $\beta$-glukosidase akan memberikan efek positif yang signifikan terhadap peningkatan yield etanol bahkan bisa sampai lebih dari dua kalinya dibandingkan yield etanol tanpa penambahan $\beta$-glukosidase.

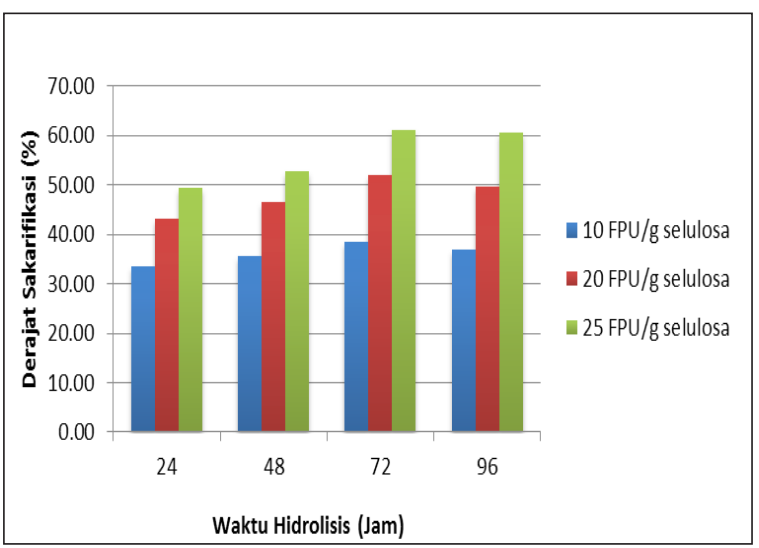

Gambar 2. Derajat Sakarifikasi

\section{Percobaan Fermentasi Glukosa menjadi Etanol}

Percobaan ini merupakan proses lanjutan dari hasil percobaan proses hidrolisis. Substrat hasil proses hidrolisis yang dilakukan pada kondisi optimum, dilanjutkan ke proses fermentasi pada suhu $28^{\circ} \mathrm{C}, \mathrm{pH} 4,5$ dengan konsentrasi inokulum Saccharomyces cerevisiae $10 \%$ serta variasi inkubasi pada 24 jam, 48 jam, 72 jam, dan 96 jam. Kadar etanol yang dihasilkan dari proses fermentasi dapat dilihat pada Gambar 3.

Berdasarkan data pada Gambar 3, dapat dijelaskan bahwa kadar etanol meningkat seiring dengan makin lamanya waktu fermentasi. Efisiensi fermentasi tertinggi diperoleh pada lama inkubasi 96 jam yaitu mencapai 78,46\% dengan kadar etanol sebesar $0,77 \%$.

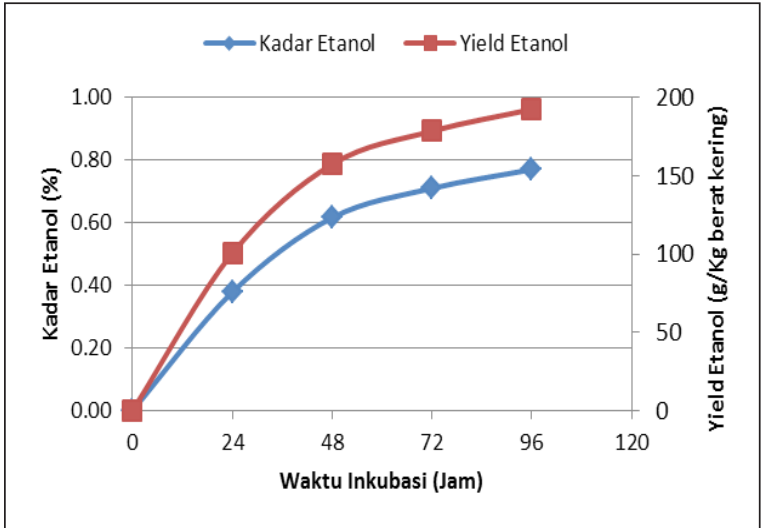

Gambar 3. Kadar Etanol Hasil Fermentasi

Secara keseluruhan efisiensi konversi selulosa pada lumpur primer IPAL industri kertas menjadi etanol adalah $46,61 \%$ dengan yield yang diperoleh terhadap lumpur yang digunakan adalah 192,5 g/ $\mathrm{kg}$ berat kering. Hasil percobaan tersebut masih rendah dibandingkan dengan hasil percobaan yang telah dilakukan oleh Peng dan Chen (2011) yang menghasilkan efisiensi konversi selulosa $56,3 \%$ dengan yield etanol terhadap berat kering lumpur primer IPAL adalah $190 \mathrm{~g} / \mathrm{kg}$. Hal tersebut, dapat diprediksi berdasarkan derajat sakarifikasi yang diperoleh relatif lebih rendah karena adanya perbedaan perlakuan enzimatik. Penambahan $\beta$-glukosidase dapat meningkatkan derajat sakarifikasi dengan menghilangkan pengaruh inhibitor selobiosa terhadap aktivitas selulase (Sun dan Cheng, 2002). Semakin tinggi derajat sakarifikasi akan semakin banyak glukosa yang dapat dirubah menjadi etanol sehingga akan semakin tinggi pula kadar etanol yang dihasilkan dari proses fermentasi. Konversi secara simultan glukosa yang dihasilkan dari proses sakarifikasi menjadi etanol dapat menghindari terjadinya akumulasi glukosa yang berpotensi menghambat kinerja enzim. Dengan metode proses produksi bioetanol melalui sakarifikasi dan fermentasi serentak diharapkan dapat meningkatkan kadar bioetanol yaitu akibat meningkatknya derajat sakarifikasi dengan menghilangkan inhibitor dari akumulasi produkproduk sakarifikasi (Cheng, 2010).

\section{KESIMPULAN}

1. Karakteristik lumpur primer IPAL industri kertas yang mengandung selulosa tinggi dan lignin rendah, menunjukkan adanya potensi untuk dimanfaatkan sebagai bahan baku bioetanol. 
2. Melalui proses dua tahap kondisi yang terbaik pada proses hidrolisis lumpur primer IPAL adalah pada dosis selulase $25 \mathrm{FPU} / \mathrm{g}$ selulosa dengan waktu 72 jam, menghasilkan kadar glukosa sebagai gula pereduksi 1,92\% dengan derajat sakarifikasi $61,05 \%$. Efisiensi proses fermentasi glukosa hasil sakarifikasi selulosa adalah $78,46 \%$.

3. Secara keseluruhan, efisiensi konversi selulosa pada lumpur primer IPAL menjadi bioetanol adalah $46,61 \%$ dengan yield bioetanol 192,5 g/kg berat kering.

\section{SARAN}

Perlu dilakukan penelitian lebih lanjut untuk mengoptimalkan produksi glukosa hasil hidrolisis selulosa sehingga etanol yang dihasilkan dari proses fermentasi dapat lebih banyak.

\section{DAFTAR PUSTAKA}

Bessou, C. F. Ferchaud, B. Gabrielle, dan B. Marry., 2011, Biofuels, Greenhouse Gases and Climate Change, Sustainable Agriculture, Vol. 2, 365-459.

Cheng, J.J., 2010, Biological Process for Ethanol Production dalam Biomass to Renewable Energy Process, CRC Press Taylor \& Francis Group. New York. Hal 223, 234.

Fan, Z dan L. R. Lynd., 2007, Conversion of Paper Sludge to Ethanol. I: Impact of Feeding Frequency and Mixing Energy Characterization, Bioprocess Biosyst Eng. No. 30, 27-34

Gavrilescu, D., 2008, Energy From Biomass in Pulp and Paper Mills, Environmental Engineering and Management Journal, Vol.7, No.5, 537-546

Kerstetter, J.D., L. Lynd, K. Lyford, dan C. South., 1996, Assessment of Potential for Conversion of Pulp and Paper Sludge to Ethanol Fuel in The Pacific Northwest, Washington (USA): National Renewable Energy Laboratory.

Lee, S.H., Y. Teramoto, dan T. Edo., 2009, Enzymatic Saccharification of Woody Biomass Micro/Nanofibrillated by Continuous Extrusion Process I - Effect of Additives with Cellulose Affinity. 2009. Bioresource Technology, Vol. 100, 275-279.
Lynd, L. R., K. Lyford, C. R. South, P. V. Walsum, dan K. Levenson., 2001, Evaluation of Paper Sludges for Amenability to Enzymatic Hydrolysis and Conversion to Ethanol. TAPPI Journal.Vol. 84(2).

Monte, M.C., E. Fuente, A. Blanco, dan C. Negredo., 2009, Waste Management from Pulp and Paper Production in The European Union, Waste Management. Vol. 29, 293308.

Mussatto, S.I., M. Fernandes, A.M.F. Milagres, dan I.C. Roberto., 2008, Effect of Hemicellulose and Lignin on Enzymatic Hydrolysis. Enzyme and Microbial Technology, Vol. 43, 124-129.

Peng, L., dan Y. Chen., 2011, Conversion of Paper Sludge to Ethanol by Separate Hydrolysis and Fermentation (SHF) Using Saccharomyces cerevisiae. Biomass and Bioenergy, Vol. 35, Hal 1600-1606.

Silva, P, W. Magalhães, C. Helm, E. Lima, D. Mendes, dan T. Lima., 2011, Evaluation of The Enzymatic Digestibility of Paper Industry by products, BMC Proceedings. Vol. 5 (Suppl 7) : P117

Soetopo, R. S., K. Septiningrum, dan A. Surachman., 2010, Potensi Kompos dari Limbah Padat Joss Paper untuk Meningkatkan Produktivitas Tanaman. Jurnal Selulosa, Vol. 45, No. 1, Hal 32-43.

Sun Y., dan J. Cheng., 2002, Hydrolysis of Lignocellulosic Materials for Ethanol Production: A Review. Bioresource Technology. Vol. 83, Hal. 1-11

Wang, Z., dan D.R. Keshwani., 2010, Biomass resources dalam Biomass to renewable energy proses. CRC Press Taylor \& Francis Group. New York. USA. Hal 50, 59

Ximenes, E., Y. Kim, N. Mosier, B. Dien, dan M. Ladisch., 2011, Deactivation of Cellulases by Phenols. Enzyme and Microbial Technology. Vol. 48, 54-60.

Yue, Z., W. Bin, Y. Baixu, dan G. Peiji., 2004, Mechanism of Cellobiose Inhibition in Cellulose Hydrolysis by Cellobiohydrolase. Science in China Ser. C Life Sciences. Vol.47, No.1, 18-24. 